\title{
RECENZIÓ „A MENTÁLIS BETEGSÉG BÉLYEGE” CÍMŰ KÖNYVRŐL
}

\author{
A recenzió szerzője: \\ Godó Katalin \\ Debreceni Egyetem (Magyarország) \\ Első szerző e-mail címe: \\ katalin1en@gmail.com
}

\author{
Lektorok: \\ Ceglédi Tímea (PhD) \\ Debreceni Egyetem (Magyarország) \\ Iványi Zsuzsanna (PhD) \\ Debreceni Egyetem (Magyarország)
}

Godó Katalin (2021). Recenzió „A mentális betegség bélyege” című könyvről. Recenzió. Különleges Bánásmód, 7. (2). 129-131. DOI 10.18458/KB.2021.2.129



Jelen recenzió alapjául szolgáló mủ bibliográfiája:

Sztancsik Veronika (2019): A mentális betegség bélyege.[Stamp of Mental Illness.] Oriold és Társai Kiadó, Debrecen. ISBN: 978-615-598101-2

Kép forrása: E-ötvös.com (URL: https://e-otvos.com/a-mentalis-betegseg-belyege. Letöltés ideje: 2021. 05. 12.)

Kulcsszavak: előítéletek, megbélyegzés, mentális stigmatizáció

Diszciplina: pszichológia, gyógypedagógia

Keywords: prejudices, stigmatization, mental stigmatization

Disciplines: psychology, special-needs education

\section{Bevezetés}

Sztancsik Veronika A mentális betegség bélyege (2019) című kötete mintegy tükröt tart az olvasónak a mentális betegek megbélyegzésével kapcsolatos problémákról, mely a jelenlegi COVID-19 pandémia okozta bezártság és az ennek következtében kialakuló mentális problémák idején még inkább aktuális és releváns lehet. A mű átfogó, komplex képet ad a témáról, tartalma rendszerező, összegző szemléletet mutat. A szöveg számos szakirodalomra hivatkozik, mely a szerző témában való jártasságát igazolja az olvasó számára.

\section{Első benyomás}

A könyv címe érzékletesen vetíti elő a könyv tartalmának fókuszát, s egyúttal azt a kijelentést is involválja, miszerint a mentális betegség egyben egyfajta „bélyeg” a hordozója számára, s egyidejű velejárója a címkézés aspektusa. A kötet borítóján egy tömeget láthatunk, mely rámutat arra, hogy a diszkrimináció alapvetően társas környezetben nyer értelmet, ugyanakkor a képen szereplő tömeg a mentális betegségek „láthatatlanságára” is rámutat, az említett bélyeg vagy stigma ugyanis csak közelebbről válik láthatóvá. Ezek a stigmák azonban nemcsak kívülről érkezhetnek, hanem belsővé is válhatnak: a külső megítélés tehát a belső megítéltetés, az önstigma alapja is lesz, s így a személy önértékelését, énképét is megkérdőjelezheti. A mentális betegségek továbbá a megbélyegzés következtében egyfajta ördögi körré, önmagát gerjesztő negatív spirállá is válhatnak, hiszen az egyén 
kezdeti betegsége a betegséggel járó nonkonform viselkedés következtében stigmatizációt válthat ki a társadalomból, mely az izoláció által tovább erősítheti a meglévő tüneteket. Így aztán a mentális betegek az elmagányosodás veszélyének kitett célcsoporttá válnak, ugyanis a környezet negatív reakciója elősegíti a „mi” és az „ő” különválasztását, differenciálását. A másik ledegradálása, lekicsinylése, megalázása a másik oldalon a pozitív énérzést (az „én jobb vagyok" érzését), a hatalmat konstruálja meg, s bizonyos esetekben növeli ezzel a csoportkohéziót.

A mentális betegségek bélyegének első, bevezetô fejezetében a Szerző rendkívül személyes hangot üt meg, mely segít közelebb hozni egy igen komoly és nehéz témát az olvasóhoz. Sztancsik Veronika ebben a fejezetben őszintén vall magáról, s bizonyos élethelyzeteibe is betekintést enged, így mutatva meg az olvasónak a könyv megírása mögött meghúzódó motivációt. A mú vállalásának célja nem kevesebb, mint lerántani a leplet a mindennapi élet mentális betegeivel szemben tanúsított ellenséges bánásmódról, amely sok esetben tudattalanul, látens formában, a társadalom gördülékeny múködésének részeként van jelen. Jól illusztrálja ezt a szerző példájában említett orvos-páciens kapcsolatban a jóváhagyja kifejezés is, amikor úgy vélik, hogy az egyén helyett mások dönthetnek, mert ő maga nem képes kontrollálni életét.

A könyv négy nagyobb egységre tagolódik, a szöveg jól strukturált, jól megtervezett, egyenes út mentén vezeti végig az olvasót a téma egyes kérdéskörein. A bevezetést A mentális állapotok betegségszemlélete c. fejezet követi, melyben fogalmi tisztázásra kerül sor, illetve a mentális betegségek orvosi kezelésének és értelmezésének történetébe nyerhetünk betekintést. A második Mi a megbélyegzés? című fejezetben a megbélyegzés jellemzői, fajtái, folyamata, a mögöttes okok és magyarázatok kerülnek bemutatásra. A mentális betegségek megbélyegzésének ártalmai címet viselő fejezet a stigmatizáló attitűdök kapcsolatokra, személyiségre, közösségekre és a szakemberek atttitűdjeire mutat rá. Végül a könyv utolsó részében (Hogyan csökkenthető a megbélyegzés és káros hatása?) a megoldási lehetôségek kerülnek fókuszba, így az olvasmány végére eszközt kaphatunk arra vonatkozóan, hogy hogyan tehetünk mi magunk a stigmatizáció ellen.

A Szerző érzékenyen közelít témájához, a szövegből a szolidaritás és együttérzés hangján szól olvasóihoz. Kifinomult fogalomhasználata is erre utal, ugyanis a Szerzô részletesen tárgyalja az egyes kifejezések árnyaltságát (mint például sztereotípia, előítélet, diszkrimináció, címkézés stb.), világos és pontos definíciók meghatározására törekszik, melyek tisztázása különösen fontos egy ilyen érzékeny téma taglalásakor.

\section{Az egyes fejezetek részletes bemutatása}

A könyv első részében a betegség definíciós kísérlete történik meg, utalva ugyanakkor ennek a problematikusságára, a külső környezet megítélésétől való függésére. Tehát a mikroközösség mellett a makroközösség, vagyis a kultúra befolyása is jelentős lehet. A fejezet során kronologikus sorrendben halad végig a szerző a különféle korok betegségészlelésénazokat egymáshoz hasonlítva, míg végül bemutatja a betegség fogalma körüli jelenlegi álláspontokat, a mentális betegségek körüli sztereotipikus tartalmakat. Szó esik a pszichiátria és a pszichológia eltérô módszereiről, eltérő gyakorlatáról. A könyv alcíméhez híven (A pszichológia gyakorlata) a Szerző pszichológiai megközelítésben mutatja be a mentális betegségek értelmezési módjait és kereteit, s elhatárolódik a pszichiátria szigorúan medikális szemléletétôl. A fejezetben szó esik a testi és lelki tünetek kölcsönhatásáról is, mely szerint a testi tünetek a lelki állapotokra adott válaszreakcióként is értelmezhetők, ugyanakkor az is fontos, hogy minden ember egyedi, s ezért minden probléma egyben sajátos színezetet is kap. A könyvet ezeknek az egyedi történeteknek a kihangosításaként is értelmezhetjük, hiszen mindvégig 
érezhető a Szerző azon törekvése, hogy változtatást érjen el, és rámutasson a mentális betegséggel élőket érintő stigmatizáció okozta károkra. A fejezet gyengeségeként tekinthetünk arra, hogy a problémakör konkrét bemutatására kizárólag a skizofrénián keresztül kerül sor, így a gazdag élményanyag ellenére hiányérzet maradhat az olvasóban, aki arra számított, hogy a skizofrénián túl más betegségről is szó esik majd a mentális betegségek témakörén belül.

A második fejezetben a megbélyegzés válfajairól, hatásairól, a diszkrimináció, előítélet, stigmatizáció jelenségéről tudhatunk meg többet. A szöveg szemléletesen mutatja be a stigmatizáció okait, mögöttes motívumait. A mentális betegséggel élők megbélyegzése a többség szempontjából többféle „haszonnal" is járhat: a probléma individualizációja lehetővé teszi, hogy ne kelljen felülvizsgálni azokat a társadalmi, kulturális normákat, melyek mentális betegségekhez vezethetnek, az ezekkel küzdők izolációja pedig megvédheti a többséget, hiszen ezeket a személyeket gyakran veszélyesként azonosítják.

A harmadik fejezetben a fókusz a megbélyegzett személyekre kerül, az ô nézőpontjukat láttatja. Elôkerülnek a laikus ember alkotta címkék, bélyegek, mellyel szembesül egy mentális betegséggel küzdő egyén, valamint ezek az egyén énképére, önértékelésére gyakorolt negatív hatásairól is szó esik. A könyv szerint a stigmatizáció hatására a személy társas kapcsolatai is sérülnek, illetve a társadalmi beilleszkedését is megnehezíti ez a folyamat.
Fontos rész az utolsó fejezet, ahol közösségi megoldási javaslatokat sorakoztat fel a szerző, külföldi mintákat is alapul véve. Mindemellett azonban kiderül az is, hogy ezidáig kevés az olyan hazai kezdeményezés, ami illeszkedik a nemzetközi jó gyakorlatok sorába. Mind a szakemberek, mind az egészségügyi rendszer szemléletmódja megreformálásra szorul, ezek ugyanis nemhogy gátolnák a sztereotípiák lebontását, sok esetben rejtetten fokozzák azt.

\section{Lezárás}

A könyv nyelvezete tudományos, ugyanakkor érthető, követhető, a stílusa pedig - az egyszerzős munkák előnyeként - egyenletes. A laikusok számára ismeretlen szakkifejezések többségében tisztázásra kerülnek (pl. reziduális, prognózis, remisszió, inkoherens beszéd, interperszonális kapcsolatok, epigenetikai kutatások, stb.) A precizitás, a sokfelől szerzett tudás egy anyagba való rendszerezése jól tükröződik a mú egészén.

A könyv alkalmas arra, hogy elősegitse a mentális betegségekkel élők iránti érzékenységet, azonban címe alapján célközönségét tekintve többségében feltehetően szakemberek, s a tárgyalt témakörökre érzékenyebb laikusok forgatják majd. Így kérdés, hogy valóban eljut-e azokhoz, akiknek a leginkább szüksége lenne az érzékenyítésre. A kötet szélesebb körökben való terjesztése hozzájárulhatna a stigmák lebontásához, így érdemes lehet azt például egyetemi kurzusok kötelező/ajánlott olvasmányává tenni. 